\title{
Brazeability of the 6061-T6 Aluminum Alloy with Al-Si-20Cu-Based Filler Metals
}

\author{
L.C. Tsao, T.C. Tsai, C.S. Wu, and T.H. Chuang
}

(Submitted 5 January 2001)

\begin{abstract}
The bond strength of the 6061-T6 aluminum alloy brazed with $\mathrm{Al}-12 \mathrm{Si}$, Al-9.6Si-20Cu, and Al-7Si-20Cu2Sn filler metals at a low temperature of $550{ }^{\circ} \mathrm{C}$ is evaluated. The fractography of these brazements after tensile tests was observed using scanning electron microscopy (SEM). It was found that joints with good integrity can be produced with $\mathrm{Al}-7 \mathrm{Si}-20 \mathrm{Cu}-2 \mathrm{Sn}$ filler metal because it can be used in a temperature range of 504 to $526{ }^{\circ} \mathrm{C}$, about $70{ }^{\circ} \mathrm{C}$ lower than the traditional Al-12Si filler metal. It was shown that joints of 6061-T6 aluminum alloy as the base metal, when brazed at $550{ }^{\circ} \mathrm{C}$ for $60 \mathrm{~min}$ using this new filler metal and ward, and after being subjected to a T6 treatment, possessed a high bonding strength of about $121 \mathrm{MPa}$.
\end{abstract}

Keywords 6061-T6 aluminum, Al-12Si, Al-Si-20Cu, brazeability, filler metals

\section{Introduction}

With advantages, such as high specific strength, low cost, and superior corrosion resistance, aluminum and its alloys have been widely used in the aerospace, automobile, and construction industries. Also, owing to their good thermal conductivity, they are often employed as heat exchangers. Brazing has been considered as one of the most important joining methods for manufacturing aluminum components. ${ }^{[1]}$ Commercially available filler metals for aluminum brazing were usually based on an aluminum-silicon alloy system with compositions around the Al-12Si eutectic. ${ }^{[2,3]}$ However, in order to achieve the strong joints, the very act of brazing with $\mathrm{Al}-\mathrm{Si}$ filler metals must be performed in the temperature range of 590 to $610{ }^{\circ} \mathrm{C}$, which is near or even above the melting point of many aluminum alloys. As a result, the aluminum workpieces after brazing would be molten either wholly or partially, or their mechanical properties would degenerate substantially.

There clearly exists a demand to develop newer filler metals with lower melting points for brazing most of the aluminum engineering alloys. Many efforts have been made for this purpose in the past ten years. Humpston et al. ${ }^{[4]}$ and Jacobson et al. ${ }^{[5]}$ reported on an $\mathrm{Al}-5 \mathrm{Si}-20 \mathrm{Cu}-2 \mathrm{Ni}$ filler metal with a melting range within 518 to $538{ }^{\circ} \mathrm{C}$. When this filler metal is brazed with a $3001 \mathrm{Al}$ alloy, shear strength over $75 \mathrm{MPa}$ is obtained. Earlier, Suzuki et al. ${ }^{[6]}$ had introduced a eutectic Al-4.2Si-40Zn filler metal with a $535{ }^{\circ} \mathrm{C}$ melting point, but the disadvantage of their filler metal lies in the very high vapor pressure of zinc, which could constitute quite an impediment to the vacuumbrazing process. In this study, a new Al-7Si-20Cu-2Sn filler metal is developed for the brazing of aluminum alloys. Its

L.C. Tsao and T.C. Tsai, Institute of Materials Science and Engineering, National Taiwan University, Taipei 106, Taiwan, Republic of China; and C.S. Wu and T.H. Chuang, Metal Industries Research \& Development Center, Kaohsiung 811, Taiwan, Republic of China. Contact e-mail: tunghan@ccms.ntu.edu.tw. brazeability with the 6061-T6 aluminum alloy is better than $\mathrm{Al}-12 \mathrm{Si}$ and the Sn-free Al-9.6Si-20Cu filler metals.

\section{Experimental}

The Al-Si-20Cu-based filler metals were prepared by melting components in $\mathrm{Al}_{2} \mathrm{O}_{3}$ crucibles placed in an air furnace. First, the Al-12Si alloy was melted at $700{ }^{\circ} \mathrm{C}$, and then, the temperature was raised to $1000{ }^{\circ} \mathrm{C}$. Copper in a shape of slugs ( 99.9 wt.\% and $2 \mathrm{~mm}$ diameter) was added into the molten $\mathrm{Al}-$ $12 \mathrm{Si}$ alloy in the amount of about $20 \%$ of the total weight. Afterward, the mixture was stirred for $30 \mathrm{~min}$ for homogenization. A part of the Al-Si-20Cu alloy was alloyed with tin. Afterward, the final $\mathrm{Al}-7 \mathrm{Si}-20 \mathrm{Cu}-2 \mathrm{Sn}$ composition was cast into a stainless steel mold. In previous authors' article, ${ }^{[7]}$ the melting ranges for both $\mathrm{Al}-\mathrm{Si}-20 \mathrm{Cu}$-based filler metals, i.e., Al-9.6Si-Cu and $\mathrm{Al}-7 \mathrm{Si}-20 \mathrm{Cu}-2 \mathrm{Sn}$, as analyzed by differential thermal analysis, were 524 to $543{ }^{\circ} \mathrm{C}$ and 504 to $526{ }^{\circ} \mathrm{C}$, respectively.

For the evaluation of brazeability of both these filler metals, 6061-T6 aluminum cylindrical specimens having $50 \mathrm{~mm}$ length and $22 \mathrm{~mm}$ diameter were employed. In preparation for bonding, the specimen surfaces were ground with 400 grit $\mathrm{SiC}$ paper; then, they were cleaned by rinsing in distilled water followed by ultrasonic cleaning in acetone for $5 \mathrm{~min}$. Table 1 shows the chemical compositions, solidus and liquidus, and the ultimate tensile strength of the 6061-T6 joints.

A $0.2 \mathrm{~mm}$ thick filler-metal foil was inserted between two 6061-T6 aluminum bars. The new alloy was brazed at $550{ }^{\circ} \mathrm{C}$ in a vacuum furnace under a pressure of $5 \times 10^{-5}$ torr, whereas a traditional Al-12Si filler metal was brazed at $600{ }^{\circ} \mathrm{C}$. After brazing, some specimens were postheat treated under the T6temper condition, i.e., the solid solution at $520{ }^{\circ} \mathrm{C}$ for 1.5 $\mathrm{h}$, water quenching, and then aging at $175^{\circ} \mathrm{C}$ for $8 \mathrm{~h}$. The microstructures of the brazed joints were observed using optical microscopy and scanning electron microscopy (SEM). Etching in $10 \mathrm{vol} . \% \mathrm{H}_{3} \mathrm{PO}_{4}$ at $50{ }^{\circ} \mathrm{C}$ for $60 \mathrm{~s}$ was employed.

In order to evaluate the bond strength, the average ultimate tensile stress at room temperature was determined at a stain rate of $10^{-3} \mathrm{~s}^{-1}$ averaging data on three brazed specimens. Figure 1 shows dimensions of the tensile test specimens. 


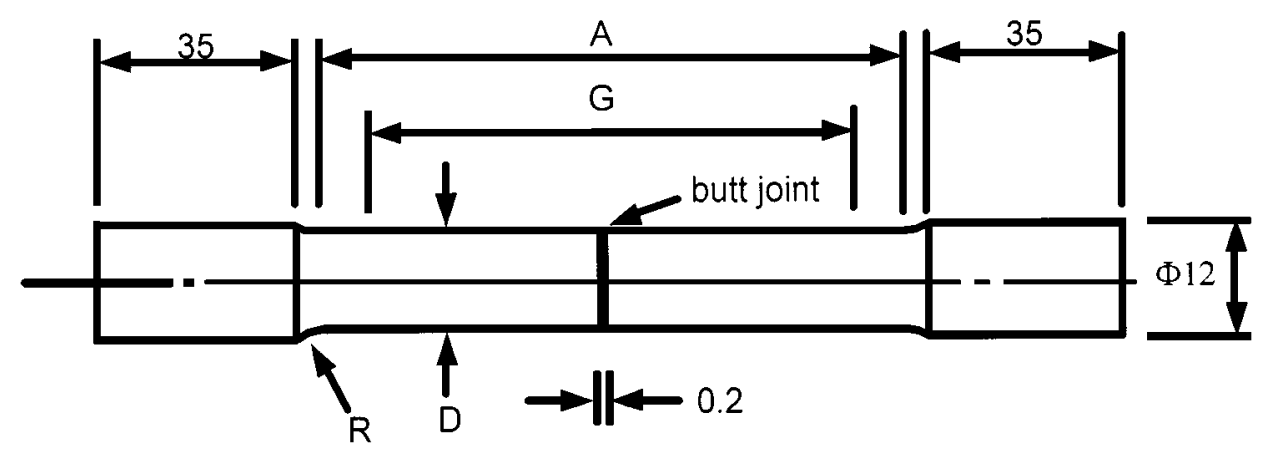

\begin{tabular}{|c|c|}
\hline G: Gage length & $50.00 \pm 0.06 \mathrm{~mm}$ \\
\hline D: Diameter & $10.00 \pm 0.02 \mathrm{~mm}$ \\
\hline R: Radius of fillet, $\min$ & $4 \mathrm{~mm}$ \\
\hline A: Length of reduced section, $\min$ & $60 \mathrm{~mm}$ \\
\hline
\end{tabular}

Fig. 1 Dimensions of the joint tensile specimen
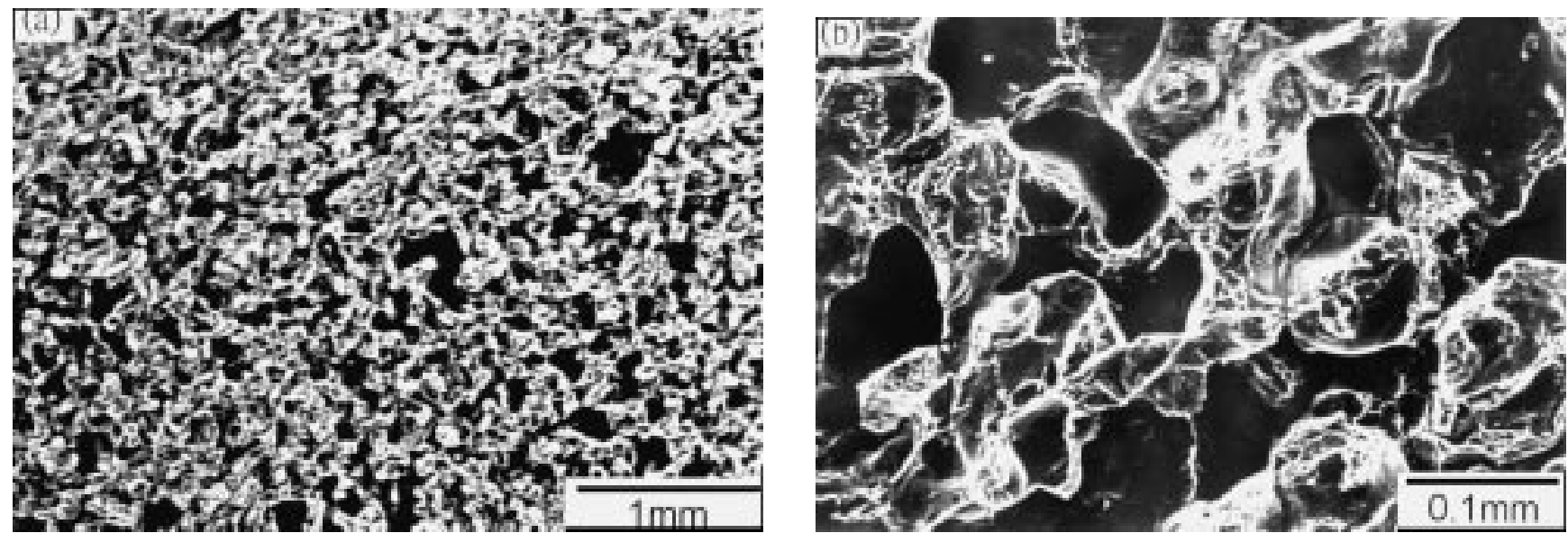

Fig. 2 (a) The SEM tensile fractured surface of the Al-12Si/6061-T6 joint after brazing at $600{ }^{\circ} \mathrm{C}$ for 30 min and (b) an enlarged detail of (a)

Table 1 Chemical composition, solidus $\left(T_{S}\right)$ and liquidus $\left(T_{L}\right)$, and the ultimate tensile strength $\left(\sigma_{\mathrm{UTS}}\right)$ of the 6061-T6 alloy

\begin{tabular}{|c|c|c|c|c|c|c|c|c|c|}
\hline \multirow[b]{2}{*}{ Alloy } & \multicolumn{6}{|c|}{ Chemical composition (wt.\%) } & \multirow[b]{2}{*}{$T_{S}\left({ }^{\circ} \mathbf{C}\right)$} & \multirow[b]{2}{*}{$T_{L}\left({ }^{\circ} \mathrm{C}\right)$} & \multirow[b]{2}{*}{$\left(\sigma_{\mathrm{UTS}}\right)(\mathrm{MPa})$} \\
\hline & Mn & Mg & $\mathbf{S i}$ & $\mathbf{C u}$ & $\mathrm{Cr}$ & Al & & & \\
\hline 6061-T6 & 0.01 & 1.10 & 0.61 & 0.25 & 0.12 & Bal. & 592 & 654 & 331 \\
\hline
\end{tabular}

\section{Results and Discussion}

The traditional Al-12Si filler metal possesses a eutectic point at about $577{ }^{\circ} \mathrm{C}$; therefore, the brazing process at 550 ${ }^{\circ} \mathrm{C}$ cannot be applied. Not until the brazing temperature is raised to $600{ }^{\circ} \mathrm{C}$ can the $6061-\mathrm{T} 6$ aluminum alloy be bonded with this filler metal. However, the joint strength remained at about $60 \mathrm{MPa}$. Evidently, brazing of a 6061-T6 alloy under such conditions results in poor quality joints. Figure 2 shows the tensile fractured surface of Al-12Si/6061-T6 brazements brazed at $600{ }^{\circ} \mathrm{C}$ for $30 \mathrm{~min}$, which contains numerous voids seen as dark areas on the photograph. Since the brazing temperature was only slightly higher than the liquidus temperature of the Al-12Si filler metal, the wettability of the molten Al12Si filler metal with respect to the 6061-T6 alloy was poor, causing formation of voids in the joining zone and a low joint strength. However, a further increase of the brazing temperature above $600{ }^{\circ} \mathrm{C}$ is inapplicable or impractical, because this 

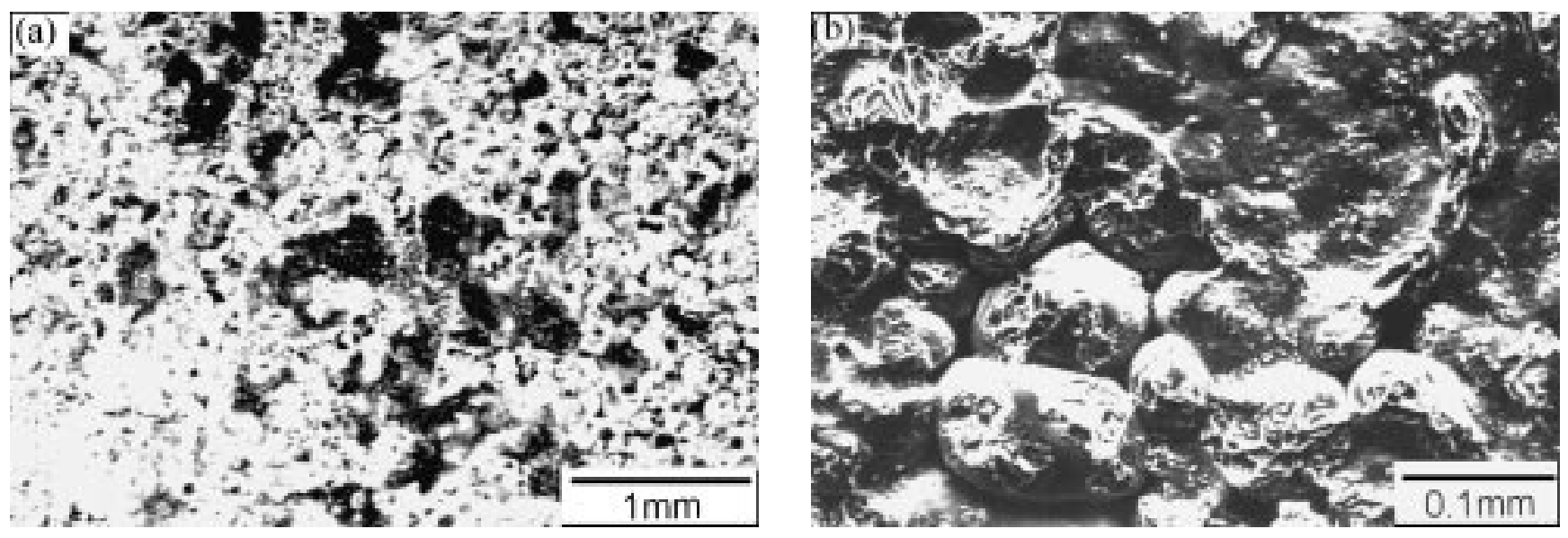

Fig. 3 (a) The SEM tensile fractured surface of the Al-9.6Si- 20Cu/6061-T6 joint after brazing at $550{ }^{\circ} \mathrm{C}$ for 30 min and (b) an enlarged detail of (a)

Table 2 Brazing conditions and the joint strength of the 6061-T6 aluminum brazements

\begin{tabular}{lccc}
\hline Filler metal & $\begin{array}{c}\text { Brazing } \\
\text { conditions }\end{array}$ & $\begin{array}{c}\text { Postheat } \\
\text { treatment } \\
\text { after brazing(a) }\end{array}$ & $\begin{array}{c}\text { Joint } \\
\text { strength, } \\
\text { MPa }\end{array}$ \\
\hline Al-12Si & $550{ }^{\circ} \mathrm{C}, 30 \mathrm{~min}$ & $\ldots$ & Failed \\
Al-12Si & $550{ }^{\circ} \mathrm{C}, 60 \mathrm{~min}$ & $\ldots$ & Failed \\
Al-9.6Si-20Cu & $550{ }^{\circ} \mathrm{C}, 30 \mathrm{~min}$ & $\ldots$ & $41 \pm 15$ \\
Al-9.6Si-20Cu & $550{ }^{\circ} \mathrm{C}, 60 \mathrm{~min}$ & $\mathrm{~T} 6$ & $56 \pm 11$ \\
Al-7Si-20Cu-2Sn & $550{ }^{\circ} \mathrm{C}, 30 \mathrm{~min}$ & $\ldots$ & $62 \pm 11$ \\
Al-7Si-20Cu-2Sn & $550{ }^{\circ} \mathrm{C}, 60 \mathrm{~min}$ & $\mathrm{~T} 6$ & $121 \pm 9$
\end{tabular}

(a) The T6-temper condition: solution treated at $520{ }^{\circ} \mathrm{C}$ for $1.5 \mathrm{~h}$, water quenched, and then aged at $175^{\circ} \mathrm{C}$ for $8 \mathrm{~h}$

might incur the risk of partial melting of the 6061 aluminum workpieces in an industrial furnace.

Figure 3 shows the fractography of the 6061-T6 aluminum joint after brazing at $550{ }^{\circ} \mathrm{C}$ for 30 min with an $\mathrm{Al}-9.6 \mathrm{Si}-20 \mathrm{Cu}$ filler metal. Since the brazing temperature was only $7^{\circ} \mathrm{C}$ higher than the liquidus $\left(543{ }^{\circ} \mathrm{C}\right)$ of this filler metal, certain areas of the surface were left unbonded and covered with solidified grains of the filler metal, as shown in Fig. 3. In this case, the joint strength, as shown in Table 2, was quite low as well. As the brazing time increased from 30 to $60 \mathrm{~min}$ and a T6-postheat treatment was rendered, the bonding strength could improve from 41 to $56 \mathrm{MPa}$. Fractography showed that there were still certain areas of the surface left unbonded. However, a few regions characterized with dimple fractures could be observed in this case, which implies that good joining occurred in these local regions (Fig. 4). A satisfactory joint could be obtained only when the brazing temperature was raised to about $570{ }^{\circ} \mathrm{C}$ in the case of the Al-9.6Si-20 Cu filler metal. When an Al-7Si$20 \mathrm{Cu}-2 \mathrm{Sn}$ filler metal was used to join the 6061-T6 aluminum alloy at $550{ }^{\circ} \mathrm{C}$ for $30 \mathrm{~min}$, the bond strength was increased to about $62 \mathrm{MPa}$. Figure 5 shows that the areas with the dimplefractured regions increased slightly in the case of $\mathrm{Al}-7 \mathrm{Si}-20 \mathrm{Cu}-$ $2 \mathrm{Sn}$. However, when the brazing time was extended to $60 \mathrm{~min}$ and then a T6 treatment rendered, the joint strength rose to 121
$\mathrm{MPa}$, a much higher value than what was obtained by Jacobson et al. when they used the $\mathrm{Al}-5 \mathrm{Si}-20 \mathrm{Cu}-2 \mathrm{Ni}$ filler metal to braze a $3001 \mathrm{Al}$ alloy. ${ }^{[5]}$ In comparison with the fractography of the cases showed in Fig. 2 through 5, many more dimple-fractured regions appeared on the surface of these specimens (Fig. 6). It was also found that the Al-7Si-20Cu-2Sn filler metal has a good wettability with respect to the 6061-T6 alloy.

It was shown that the $\mathrm{Al}-7 \mathrm{Si}-20 \mathrm{Cu}-2 \mathrm{Sn}$ filler metal produced a sound joint when brazed with the 6061-T6 aluminum alloy and carried out at a low temperature of $550{ }^{\circ} \mathrm{C}$. Figure 7 shows three different microstructures of the 6061-T6 joints brazed with Al-12Si, Al-9.6Si-20Cu, and Al-7Si-20Cu-2Sn filler metals. As is evident from these micrographs, in the case of the Al-12Si brazement prepared at $600{ }^{\circ} \mathrm{C}$ for $30 \mathrm{~min}$, the brazing zone is about $600 \mu \mathrm{m}$. However, where Al-9.6Si-20Cu and Al-7Si$20 \mathrm{Cu}-2 \mathrm{Sn}$ filler metals were used and brazing was conducted at the lower temperature of $550{ }^{\circ} \mathrm{C}$, the brazing zone is narrower, only $400 \mu \mathrm{m}$, thus resulting in a substantial improvement of the joint strength.

During brazing, the molten filler metal reacted with the tested aluminum-base metals resulting in a decrease of the concentration of elements depressing the melting temperature, such as $\mathrm{Si}, \mathrm{Cu}$, and $\mathrm{Sn}$. When the solidification stage sets in, the $\alpha$-Al solid-solution grains nucleate at the liquid/solid interface and grow toward the joint center. Since these elements have lower solubility in the $\alpha$-Al solid solution, they were rejected into the intergranular residual-liquid region. Finally, the residual-liquid phase when solidified would lie out according to its intergranular characteristics, as the morphology of the joint in Fig. 7 would illustrate. The sound joint formed in the Al7Si-20Cu-2Sn/6061-T6 brazements is attributed to the much lower liquidus of the $\mathrm{Al}-7 \mathrm{Si}-20 \mathrm{Cu}-2 \mathrm{Sn}$ filler metal in comparison with the brazing temperature, which explains its good wettability and flowability in the clearance of the studied specimens.

\section{Conclusions}

The addition of $20 \mathrm{wt} . \% \mathrm{Cu}$ into the Al-12Si alloy decreases the melting range by about $50{ }^{\circ} \mathrm{C}$. Further addition of $2 \mathrm{wt} . \%$ $\mathrm{Sn}$ into the Al-Si-Cu alloy decreases its melting temperature 

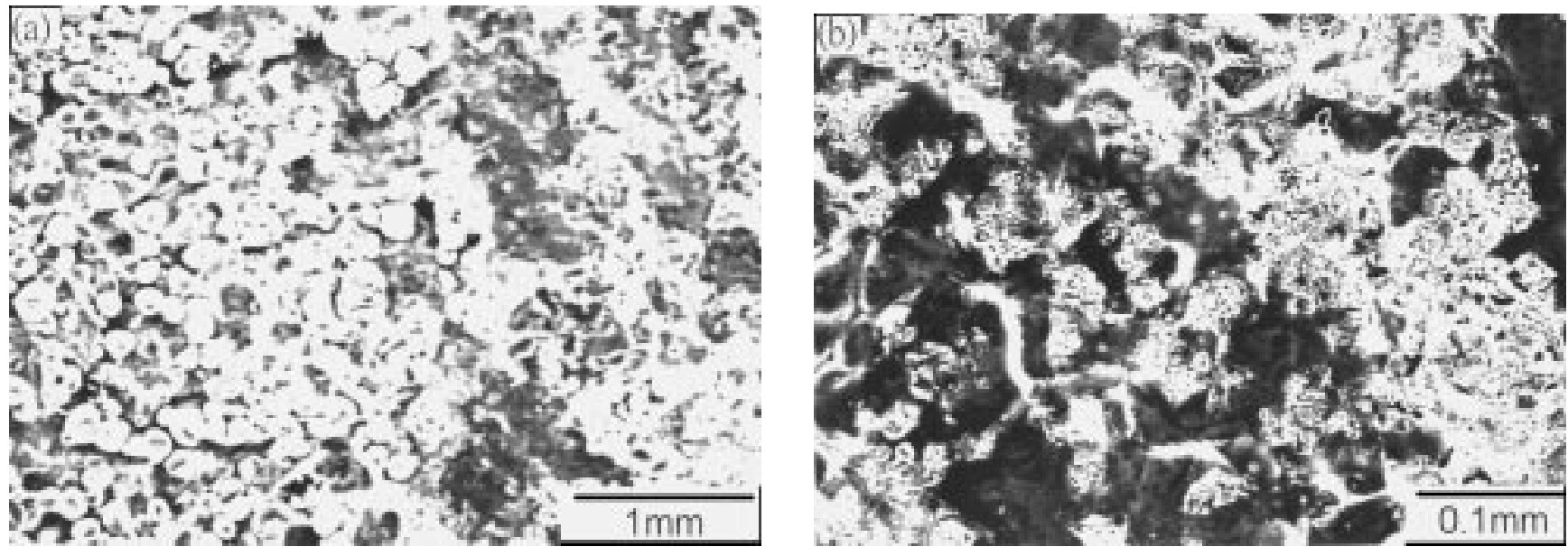

Fig. 4 (a) The SEM tensile fractured surface of the Al-9.6Si-20Cu/6061-T6 joint after brazing at $550{ }^{\circ} \mathrm{C}$ for 60 min followed by a $\mathrm{T} 6$ posttreatment and (b) an enlarged detail of (a)
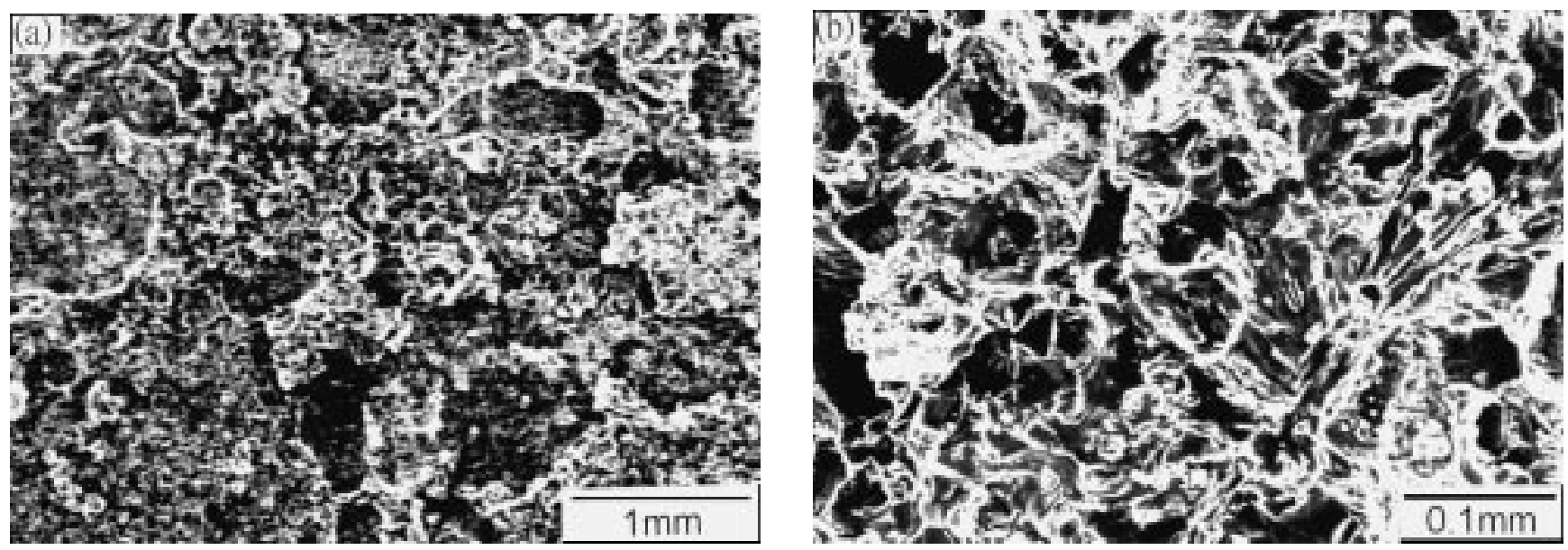

Fig. 5 (a) The SEM tensile fractured surface of the Al-7Si-20Cu-2Sn/6061-T6 joint after brazing at $550{ }^{\circ} \mathrm{C}$ for 30 min and (b) an enlarged detail of (a)
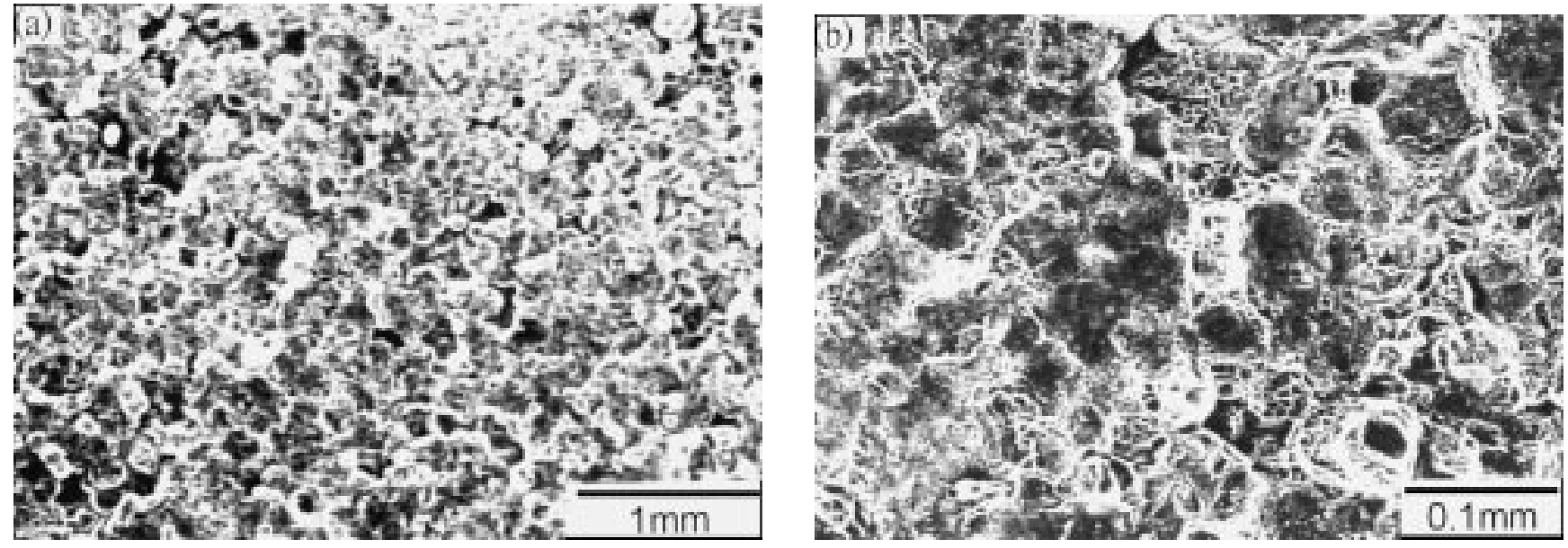

Fig. 6 (a) The SEM tensile fractured surface of the Al-7Si-20Cu-2Sn/6061-T6 joint after brazing at $550{ }^{\circ} \mathrm{C}$ for 60 min followed by a $\mathrm{T} 6$ posttreatment and (b) an enlarged detail of (a) 

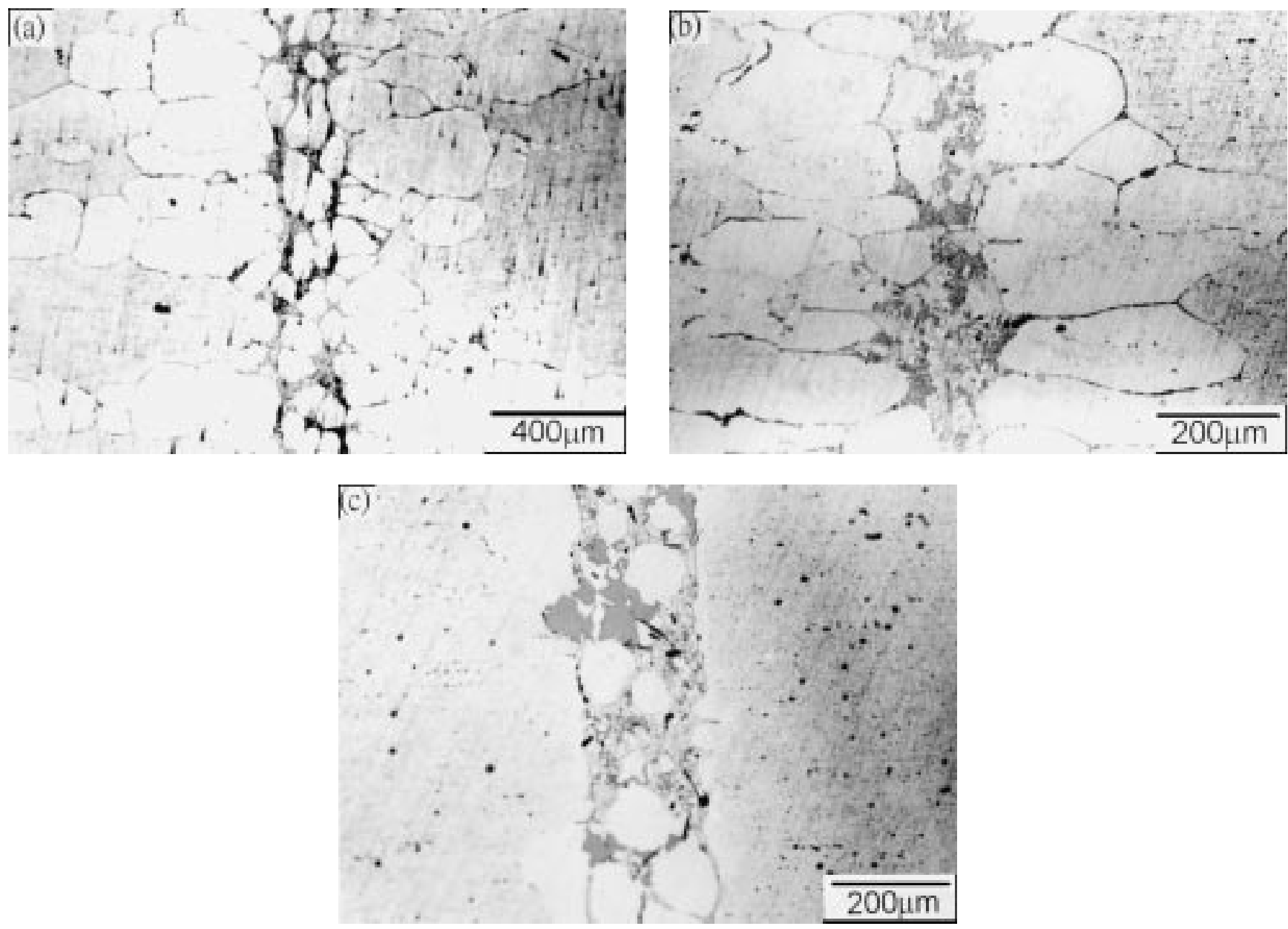

Fig. 7 Microstructure of the 6061-T6 aluminum joints after brazing with (a) Al-12Si, (b) Al-9.6Si-20Cu, and (c) Al-7Si-20Cu-2Sn filler metals

range even farther, 504 to $526{ }^{\circ} \mathrm{C}$. As the brazeability of the 6061-T6 aluminum alloy with all these filler metals at the low temperature of $550{ }^{\circ} \mathrm{C}$ is evaluated, this study concludes that the Al-7Si-20Cu-2Sn filler metal possesses an excellent wettability and a relatively high bonding strength of about $121 \mathrm{MPa}$.

\section{References}

1. Y. Sugiyama: Welding Int., 1989, vol. 3 (8), p. 700.

2. H. Kawas, T. Takemoto, M. Asano, I. Kawakatsu, and K. Liu: Welding
J., 1989, vol. 68 (10), p. 396s.

3. T. Hattori, S. Sakai, A. Sakamoto, and C. Fujiwara: Welding J., 1994, vol. 73 (10), p. 233s.

4. G. Humpston, S.P.S. Sangha, and D.M. Jacobson: Mater. Sci. Technol., 1995, vol. 11, p. 1161.

5. D. M. Jacobson, G. Humpston, and S.P.S. Sangha: Welding J., 1996, vol. 75 (8), p. 243s.

6. K. Suzuki, M. Kagayama, and Y. Takeuchi: J. Jpn. Inst. Light Met., 1993, vol. 43 (10), p. 533.

7. M.S. Yeh, L.C. Tsao, T.C. Tsai, C.S Wu, and T.H. Chuang: Metall. Mater. Trans. A, 2000, vol. 31, p. 2239. 